\title{
Egyháztörténet és állagmegóvás
}

BUZOGÁNY DEZSŐ

\section{Rövid történelmi elózmény, általános keret}

T udomásom szerint jelenleg az Erdélyi Református Egyházban állag-

megóvást csak egyetlen intézmény végez, a Pokoly Józsefről elnevezett egyesület, amely ugyanakkor egyháztörténet-kutatással is foglalkozik, tehát erről az egyesületről lesz szó az alábbiakban. A Pokoly Társaság 2012ben alakult meg. Történetéről sokat egyelőre még nem lehet mondani, annál többet az előzményeiről, és arról az útról, amely idáig vezetett. A munkacsoport múködése szorosan kapcsolódik az erdélyi református egyháztörténet kutatásához. Erdélyben az egyháztörténet-kutatásnak hosszú ideig nem alakult ki intézményes kerete. A kommunista időben két olyan intézmény is volt, amely keretül szolgálhatott volna ennek, a Protestáns Teológiai Intézet és az Erdélyi Református Egyházkerület Központi Gyújtőlevéltára (mai nevén erdélyi Református Egyházkerületi Levéltár), de az akkori viszonyok közepette szervezett intézményi háttérre még gondolni sem lehetett. A kilencvenes fordulat után új lehetőségek előtt találta magát ez a tudományág is. Nem véletlen tehát, hogy épp ez a két intézmény lett a megújuló egyháztörténet-kutatás fészke. Először a Protestáns Teológiai Intézet egyháztörténeti tanszéke indított el kutatási és könyvkiadási programot azzal a céllal, hogy fiatal kutatókat neveljen, illetve a kommunista időszak óta elfekvő és az újonnan születő egyháztörténeti munkákat kiadja. Az utánpótlás-nevelés eléggé bizonytalanul indult, de a kezdeti megtorpanások ellenére mégiscsak felgyorsult, 1999-ben pedig megszületett az Erdélyi Református Egyháztörténeti Füzetek könyvsorozat is, a már említett kettős céllal. A két intézmény akkor talált egymásra, és alakított ki amolyan félintézményi keretet, amikor 1999-ben sor került Bod Péter zsinati végzéseket tartalmazó gyúijteményének a kiadására. Azóta is sikeresen együttmúlködnek. 
Időközben új kapu nyílt meg a tudományág előtt. I993-ban megszerveződött a kolozsvári állami egyetemen a Református Tanárképző Kar, és itt 2OOI-től lehetőség adódott a mester- és a doktorképzésre. Tekintettel arra, hogy a karon magyar nyelvú oktatás folyt, és a két fokozatot anyanyelven is meg lehetett szerezni, ugyanakkor pedig a történelem szakon nem volt magyar nyelvú doktorképzés, sok történész és múvészettörténész jelentkezett a kar doktori iskolájába. Ez olyan lehetőséget csillantott fel a doktori iskola egyháztörténész tanára előtt, amelyet mindenképpen ki kellett használnia az egyháztörténet javára. Ki is használta, és a jelentkezőket többnyire az egyháztörténet vagy egyházmúvészet irányába terelte. Idő múltával az itt alakult egyháztörténészi munkaközösség mind jobban és jobban múködő szakmai közösséggé érett. Az érési folyamatban igen kiemelt szerepet kaptak az éveken át végzett rendszeres terepgyakorlatok. Amikor pedig nevet kellett választani, akkor erre a Pokoly József neve túnt alkalmasnak, aki egyike volt az I895-től Kolozsváron megalapított Református Teológiai Fakultás első tanárnemzedékének, az egyháztörténeti tanszéken. Többéves kutatómunka és előkészület után végre 20I2-ben a munkacsoport törvényesen is bejegyzett Társasággá alakult át.

\section{A Pokoly József Egyháztörténeti Múhely}

A korai Pokoly József Egyháztörténeti Múhelyt nem lehet különválasztani a későbbi Pokoly Társaságtól. Az előbbi tágabb szakmai közösséget alkotott, és amolyan mozgalom volt, az utóbbi pedig szúkebb szakmai közösség, és többé-kevésbé intézményesített kutatást és állagmegóvást végez. Vegyük sorra ezeket.

Az egyháztörténeti múhely tehát amolyan mozgalom volt, és ennek keretén belül csoportos és egyéni kutatások egyaránt történtek. A beszámolót a Protestáns Teológiai Intézetben elindított egyháztörténet-kutatással kell kezdenem. 1996-97 között csoportos kutatás keretében vettük vizsgálat alá Bod Péternek a református zsinatok végzéseiről készített gyúijteményét Albert András és Simon Anna volt teológiai hallgatókkal, és adtuk ki később i999-ben, közösen az Erdélyi Református Egyházkerületi Levéltárral. Utána, 200I-2003 között, Ôsz Sándor Előddel és még néhány akkori diákkal ugyancsak csoportos kutatást és forrásfeltárást végeztünk a Hunyad-Zarándi egyházmegyében, és ennek anyagát három kötetben jelentettük meg. Ezzel párhuzamosan a jelenkor egyháztörténetének a kutatását is elindítottuk három diákkal (Kádár Tamás, Mihály Lehel, Sebestyén Előd), 
és az egyházkerületi levéltárban, illetve a Protestáns Teológia levéltárában talált adatokból készítettük el összefoglaló kötetünket a Protestáns Teológia 1950-55 közötti életéről. Később ugyancsak teológiai hallgatók (Tőkés Attila, Szabadi Erzsébet, Gede Csongor, Kasza Erika, Barabás Attila és Bartha Réka) végeztek forrásfeltáró kutatómunkát az erdélyi református kollégiumok két háború közötti életéről, és ez gyújteményes kötetben látott napvilágot 2006-ban. Ezenkívül több kisebb cikk és tanulmány is megjelent a Református Szemlében, a két világháború közötti időszak egyháztörténetéről Barabási Endre, Gavrucza Emese, Bartha Réka és más teológiai hallgatók tollából.

Egyéni kutatásról is számot adhatunk. A Múhely által elindított programok egyikében Kurta József az Öreg graduállal foglalkozott, amelynek eredményeit külön kötetben jelentettük meg 2002-ben, aztán egyéni kutatóként múködött itt Kolumbán Vilmos József is, akinek két kötetét is sikerült megjelentetni: Törvényhozó egyház, 2002, illetve Backamadarasi Kis Gergely, 2005. Ugyancsak ide sorolható Ôsz Sándor Előd, aki a hunyad-zarándi forrásfeltárás mellett a szászvárosi református kollégium diákságának a névsorát is kiadta (megjelent 2006-ban). A felsorolt kutatások eredményeit az EREF sorozatban publikáltuk.

A felkutatott forrásanyag hatalmas mérete új sorozat elindítását tette szükségessé. Így született meg 200I-ben az Erdélyi Református Egyháztörténeti Adatok sorozat, többnyire forrásközlés céljával. Ebben csoportos és egyéni forrásfeltárások is napvilágot láttak. Jelen pillanatig 9 kötete jelent meg: az erdélyi református egyházkerület zsinati végzéseinek két kötete, a Hunyad-Zarándi Református Egyházközségek történeti katasztere 3 kötetben, a Sepsi református egyházmegye vizitációs jegyzőkönyvei I kötetben, a nagysajói káptalan egyházközségeinek történeti katasztere I kötetben, a Hunyad-Zarándi Református Egyházmegye Parciális Zsinatainak végzései I kötetben, és a Küküllői református egyházmegye parciális zsinatainak I kötete.

200I-től a Protestáns Teológia egyháztörténet-tanára meghívást kapott az állami egyetemen múködő tanárképző karra, ahol létrehozta a Pokolymúhely ottani fiókját. Az itt elindult kutatásba kapcsolódtak bele kezdetben a mesteri fokozatra jelentkező hallgatók, 2003 után pedig a tanár PhD-hallgatói. 2002-2012 között itt is több egyéni és csoportos kutatás indult. Az egyéni kutatók közül hadd emeljük ki azokat, akik a múhely szélesebb közösségéhez tartoztak: Kis Juhász Vilmos az egyházi énekanyag vizsgálatát végezte el, Szász Anikó a kolozsvári református egyházközség I7. századi életébe nyújtott betekintést, Fejér Tamás a fogarasi református iskola 
múködésének részleteit tárta fel, Gálfi Emőke a gyulafehérvári hiteleshely requisitorait mutatta be, László Kimpián Annamária a marosvásárhelyi Teleki-Bolyai könyvtár supralibrosairól írt, Tóth Levente az udvarhelyszéki református egyház patrónusainak egyházi múködését tárta fel, Straubné Rácz Etelka a Királyhágómelléki Református Egyházkerület 20. századi megalakításának a kérdéskörét vizsgálta, Kovács Mária Márta az egyházi kegyszereket, az ón- és ötvösmúveket dolgozta fel, Tamásné Horváth Iringó az egyházközségek textíliáit kutatta, Nagy Alpár Csaba a dél-erdélyi református egyházkerület életére vonatkozó levéltári anyagot tárta fel, Jánosi Csongor a volt Állambiztonsági Szolgálat levéltárában lévő adatokat gyújtötte össze a református egyház 20. század közepi életéről, Kis Zoltán a kommunista korszakban elindított kollektivizálás egyházi lecsapódását követte nyomon, Sipos Dávid pedig az egyházi orgonákat vizsgálta.

Ezek többnyire egyéni kutatások voltak. Az állami egyetemen elindított csoportos egyháztörténet-kutatásokat már csak a Múhely szúkebb közössége végezte. Kezdetben tagjai voltak Kovács Mária Márta, Tamásné Horváth Iringó és Tóth Levente, valamennyien PhD-hallgatók, és Ôsz Sándor Előd teológiai hallgató, majd levéltáros, (ő is PhD-hallgató volt, mostanára meg is védte doktori dolgozatát), később csatlakozott Sipos Dávid, ugyancsak PhD-hallgatóként (mára már ő is doktorált). 2002-2009 között közös kutatási program fogta össze őket: a Küküllői református egyházmegye egyházlátogatási jegyzőkönyveinek és parciális zsinatai végzéseinek a feltárása, sajtó alá rendezése. Kutatásaink eredményeit négy kötet foglalja össze (2008-20I2), amelyek az itt elindított Fontes Rerum Ecclesiasticarum in Transilvania sorozatban jelentek meg. 2007-20Io között elvégezték az egyházmegye gyülekezeteiben fennmaradt értéktárgyak (klenódiumok, textíliák, harangok, orgonák) és az egyházközségi levéltárak anyagának a leltározását és digitális rögzítését. A négy vaskos kötet nemcsak az egyházlátogatási jegyzőkönyvek szövegeit tartalmazza, hanem szakszerú bevezetőt, a gyülekezetek lelkészeinek és tanítóinak a névsorát, szaktanulmányokat a gyülekezetek klenódiumairól, textíliáiról és orgonáiról, továbbá részletes tárgymutatót, tematikus bontásban, és a kötetben szereplő latin szavak és kifejezések szótárát.

Összesítve a Pokoly József Egyháztörténeti Múhely eddigi termését, adatszerúen: az EREF 1999-20I5 között 20 kötetet jelentetett meg. Ebből fiatal szerzők eredeti munkája 9, a kommunista uralom alatt elfekvő írás 5, rövidebb forrásközlés 5, egyéb 2, előkészületben: Lelkész és egyházközség a kommunizmus idején. Az össztermés közel 4500 oldal. Az Erdélyi Református Egyháztörténeti Adatok sorozatban megjelent 9 kötet, közel 4000 oldal, 
a Fontes Rerum Ecclesiasticarum in Transylvania sorozatban pedig 4 kötetet sikerült kiadni, 3200 oldal dokumentumot és ezek szakszerú feldolgozását.

A Pokoly-múhely szúkebb szakmai közössége kifejezte igényét, hogy a doktori iskola elvégzése után is együtt maradjon. Ez alapján került sor 2OI2ben a tulajdonképpeni Pokoly Társaság hivatalos állami bejegyzésére, egyesületként. Tagjai: Sipos Gábor egyetemi docens, Buzogány Dezső egyetemi tanár, Kolumbán Vilmos József egyetemi tanár, öt végzett PhD-hallgató: Kovács Mária Márta muzeológus, Tamásné Horváth Iringó és Tóth Levente, az Egyesület alkalmazottja, illetve két PhD-hallgató: Ôsz Sándor Előd levéltáros és Sipos Dávid. Azóta az egykori PhD-hallgatók mind megvédték doktori értekezésüket.

A sorozatos kutatóutak tapasztalata az, hogy a meglátogatott gyülekezetekben minden baráti figyelmeztetés ellenére sem történt előrelépés az értéktárgyak és levéltári anyag megfelelő tárolására nézve. Ezért Egyesületünk elhatározta, hogy új programot indít, és végigjárja az egyházkerület valamennyi gyülekezetét, $s$ a digitalizálás és a leltározás mellett rendbeszedi a levéltárat, illetve elvégzi az értéktárgyak szakszerú tárolását is. Erre nagyobb támogatást is sikerült szerezni, és 2015 végétól az erdélyi református egyházkerület hivatalos programjaként végezte ezt a munkát, így készülvén a reformáció 500. jubileumára. A 549 gyülekezetből 228 gyülekezet anyagát részben feltártuk, részben digitalizáltuk, részben megtörtént a szakszerú állagmegóvás is. (Brassó: 30 egyházközségéből 6 egyházközséget felmértünk, a Dési egyházmegye több mint 84 egyházközségéből 23 gyülekezet felmértünk [a felsorolt 84-ből mára már számos eltúnt], Erdóvidéki: I7 gyülekezetből mind a tizenhét kész, Görgényi: 56-ból 42 megvan, Hunyadi eme: 26-ból II megvan, Kalotaszeg: 33-ból I van meg, Kézdi-Orbai: 34-ből 33 megvan, Kolozsvári: 36-ból I3 megvan; Küküllo’: 70-ből 27 megvan; Marosi: 44-ből II megvan; Maros-Mezőségi: 30-ból 5 megvan; Nagyenyed: 45-ből 9 megvan; Sepsi: 29, mind megvan; 47-ből o megvan; Torda: I5-ból I van meg.)

Tevékenységünk azonban nem merül ki csak ennyiben. Jól tudjuk, hogy nincs biztosíték arra nézve, hogy a rendbeszedett egyházközségi emlékanyag megmarad ebben a rendezett formában. Ezért rendszeres tájékoztatásokat is tartunk gyülekezeti tagoknak és helyi lelkészeknek egyaránt. Ezeken felhívjuk a figyelmet az emlékanyag történelmi és múvészi értékére, továbbá arra, hogy mennyire fontos ezeket szakszerúen tárolni és esetenként megjavíttatni, illetve tanácsokkal szolgálunk a tárolásra és javításra nézve. Ezzel párhuzamosan ugyanakkor elkezdődött a lelkész- és vallástanárjelöltek felkészítése is az állagmegóvó feladatra. 
Miben lehetne összefoglalni e jelen bemutatót? Nos, a 20. században nem alakult ki intézményes egyháztörténet-kutatás, csak egyszemélyes, tehát a tudományág, szakember hiányában, hosszú ideig nem fejlődhetett megfelelőképpen, megrekedt a félúton (valahol a múkedvelés és a szakmaiság között), és sokáig nem tudott továbblépni, következésképpen nem számíthatott a történettudomány szakmai elismerésére (egy-két egyéni teljesítménytől eltekintve). A Pokoly József Egyháztörténeti Múhely és a vele párhuzamosan múködő Pokoly Társaság egyik célja az, hogy ezt az elismerést meg- vagy visszaszerezze, és új, a szakmai színvonalnak is megfelelő szakágként legyen jelen az erdélyi és az anyaországi történettudományban. 